\title{
Diagnosis of preinvasive carcinoma of the uterine cervix
}

\author{
P. C. MEYER \\ From the Central Histological Laboratory, Whittington Hospital, London
}

SYNOPSIS The changes occurring at the periphery of invasive cervical carcinomas have been studied in detail, with particular reference to the incidence of preinvasive carcinoma. The various criteria used in the cytological diagnosis of malignancy have been evaluated, and the implications of large cytological screening programmes are discussed in a brief review of the literature.

In 1867 Beale illustrated exfoliated malignant epithelial cells while the entity of preinvasive carcinoma was probably first recognized by Williams (1888) and more clearly defined by Schauenstein (1908) although the term 'carcinoma in situ' was not introduced until 1932 by Broders. Exfoliative cytology was finally established as a routine diagnostic method in this field by the work of Papanicolaou and Traut (1943) and has been actively practised since then all over the world. Although Schottlaender and Kermauner (1912) showed histologically that precancerous changes were present at the margins of invasive carcinomas the validity of the concept of preinvasive carcinoma depends ultimately on clinical evidence (Petersen, 1955; Koss, Stewart, Foote, Jordan, Bader, and Day, 1963).

The term 'preinvasive carcinoma' is used here as synonymous with 'carcinoma in situ' but a more recent concept termed 'dysplasia' has been introduced and currently finds great favour with American workers. The boundaries of the latter condition are ill-defined and the prognosis is uncertain but a proportion develop into preinvasive carcinoma (Stern, 1959) while many examples show regression (Koss and Durfee, 1956; Figge, de Alvarez, Brown, and Fullington, 1962). The precise ratios are much debated and the general uncertainty is reflected by the accumulation of many synonyms; 16 have been listed by De Brux and Wenner-Mangen (1961). Many authors have defined histological criteria for dysplasia (Carson and Gall, 1954; Galvin, Jones, and Te Linde, 1955; Reagan, Hicks, and Scott, 1955; Nieburgs, 1963) and it has also been claimed by Reagan, Seidemann, and Saracusa (1953) and by Okagaki, Lerch, Younge, Mckay, and Kevorkian

Received for publication 23 December 1964.
(1962) that these distinctions are reflected in precise cytological distributions. More recently Richart (1963) has claimed that the two conditions may be distinguished by radioautographic analysis using tritium as a labelling agent.

Since the introduction of a cytochemical method using acridine orange by von Bertalanffy, Masin, and Masin (1956) the technique of fluorescence microscopy has become firmly established in the field of diagnostic cytology. Nevertheless, the relative value of the method compared with the purely morphological approach using Papanicolaou's technique has been much debated. Thus Törnberg, Westin, and Norlander (1960) and Elevitch and Brunson (1961) have emphasized the technical rapidity of the cytochemical method while results of equal accuracy to those obtained with the Papanicolaou method have been claimed by Dart and Turner (1959) and by Kaplan, Masin, Masin, Carleton, and von Bertalanffy (1960). It is clear that the cytochemical method yields satisfactory results only in the hands of a competent cytologist (Holland and Ackermann, 1961) but the employment of lower magnifications is a definite advantage to the microscopist as stated by Törnberg et al (1960).

The investigation of Schottlaender and Kermauner mentioned earlier has been much quoted in the literature but remains one of the few original studies on the subject. It appeared worth while, therefore, to investigate in detail the relationship between invasive cervical carcinoma and the presence of hyperplasia, metaplasia, dysplasia, and preinvasive carcinoma at its margins. At the same time the relevant uterine cervical smears in the files of this department were reviewed for critical evaluation of the criteria of malignancy suggested by previous authors. 


\section{METHOD OF STUDY}

Histological material from 300 examples of infiltrating cervical carcinoma, accumulated during the years 1944 to 1963 in the files of this department, was studied. Only biopsies and hysterectomy specimens were accepted and all cases with a history of previous irradiation were rejected. In each case the main site of the biopsy was noted and a search was made for evidence of preinvasive carcinoma affecting either the surface squamous epithelium, the cervical canal, or both. The extent of involvement by carcinoma in situ was estimated by noting the number of low-power field diameters over which a strip of surface epithelium showed the typical changes while in the case of the endocervical glands the degree of involvement was briefly described. Similar methods were used for cases showing dysplasia, metaplasia, or hyperplasia of epithelium at the margins of infiltrating tumours. In all cases the degree of cellular proliferation was determined by counting the number of nuclei in the vertical depth of the altered epithelium and noting the maximum and minimum figures.

At this point the terms mentioned must be clearly defined. Preinvasive carcinoma or carcinoma in situ implies a complete loss of the normal maturation gradient in an epithelium with replacement by a homogeneous and disorientated cell population. The latter may be completely undifferentiated, assuming a simple transitional celled structure with marked atypicality and mitotic activity: on the other hand, some attempt at differentiation may result in an epidermoid or squamouscelled structure or even a combination of these three types.

Dysplasia implies a lesser degree of dedifferentiation than that found in fully developed carcinoma in situ. There is often substantial cellular pleomorphism but a maturation gradient is still detectable and no attempt was made to subdivide the group. The terms metaplasia and hyperplasia are generally accepted and need no comment.

In the case of cervical smears stained by Papanicolaou's method various cellular criteria were sought for in atypical cells from proven examples of infiltrating and preinvasive carcinoma; the method is self-evident from the headings in Table III.

\section{RESULTS}

The findings in the case of the infiltrating tumours may be summarized as follows, The total 300 examples included 187 squamous carcinomas, 68 epidermoid carcinomas, 30 adenocarcinomas, 13 mucoepidermoid carcinomas, and two adeno-acanthomas. In this classification the epidermoid variety includes undifferentiated and transitional-celled forms. Typical examples of an adenocarcinoma, a muco-epidermoid carcinoma, an undifferentiated transitional-celled carcinoma, and a squamous-celled carcinoma are illustrated in Figs. 1, 2, 3, and 4 respectively. As far as the site of origin was concerned, the histological material

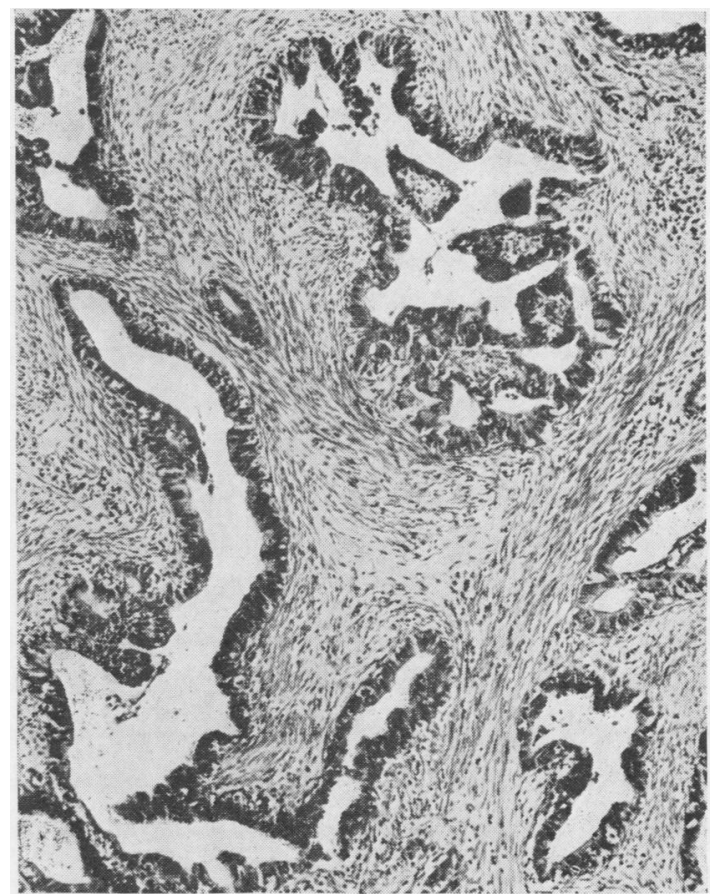

FIG. 1. Endocervical columnar-celled adenocarcinoma. Haematoxylin and eosin $\times 70$.

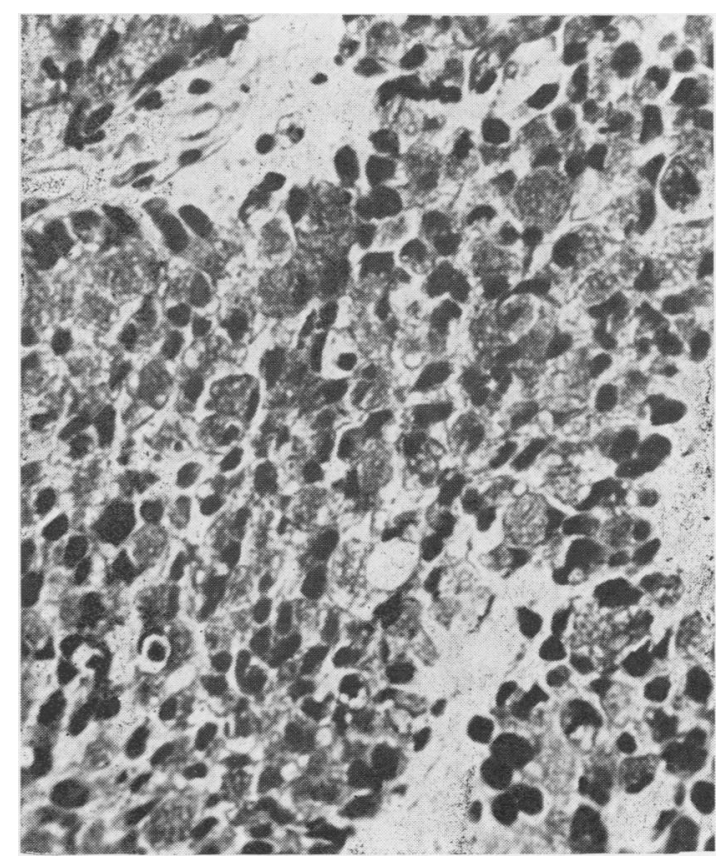

FIG. 2. Exocervical muco-epidermoid carcinoma showing vacuolated 'signet ring' cells interspersed in trabeculae of epidermoid cells. Haematoxylin and eosin $\times 300$. 


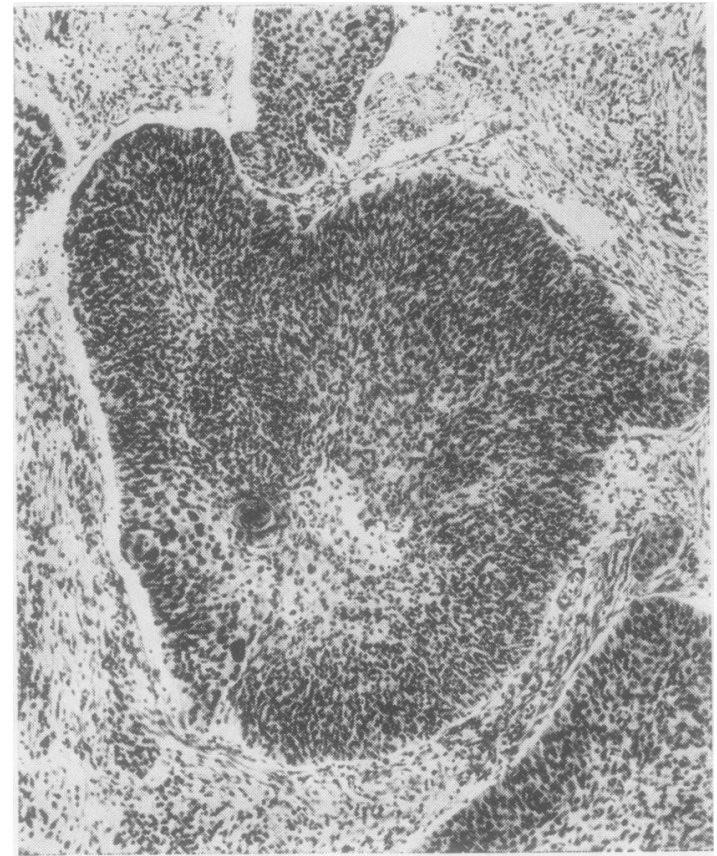

FIG. 3.

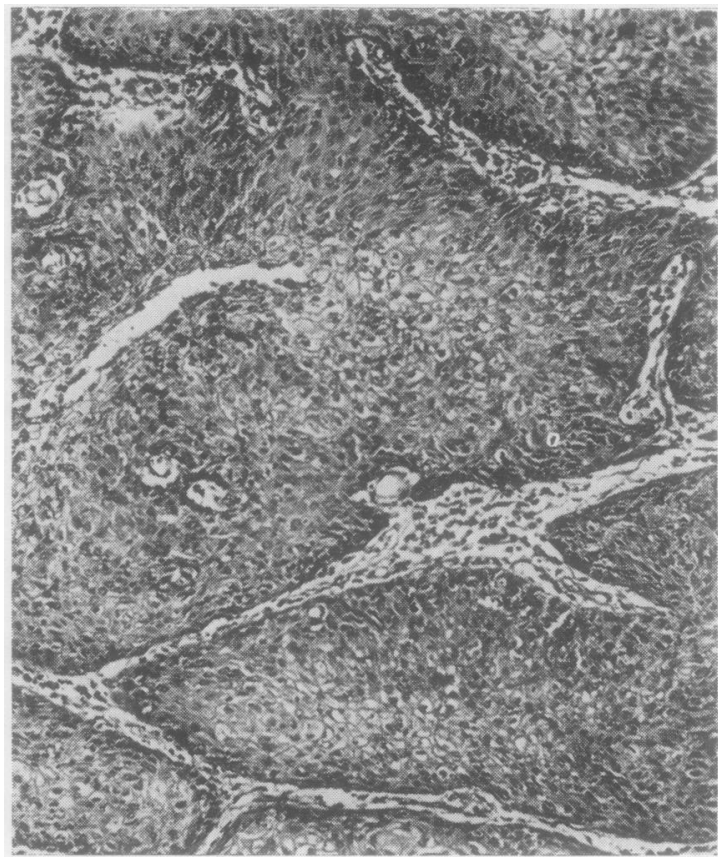

FIG. 4.



FIGS. 3 and 4. Exocervical transitional-celled carcinoma with occasional keratinized squamous foci. $(\times 75)$ and endocervical epidermoid and squamous-celled carcinoma $(\times 110)$. Haematoxylin and eosin.

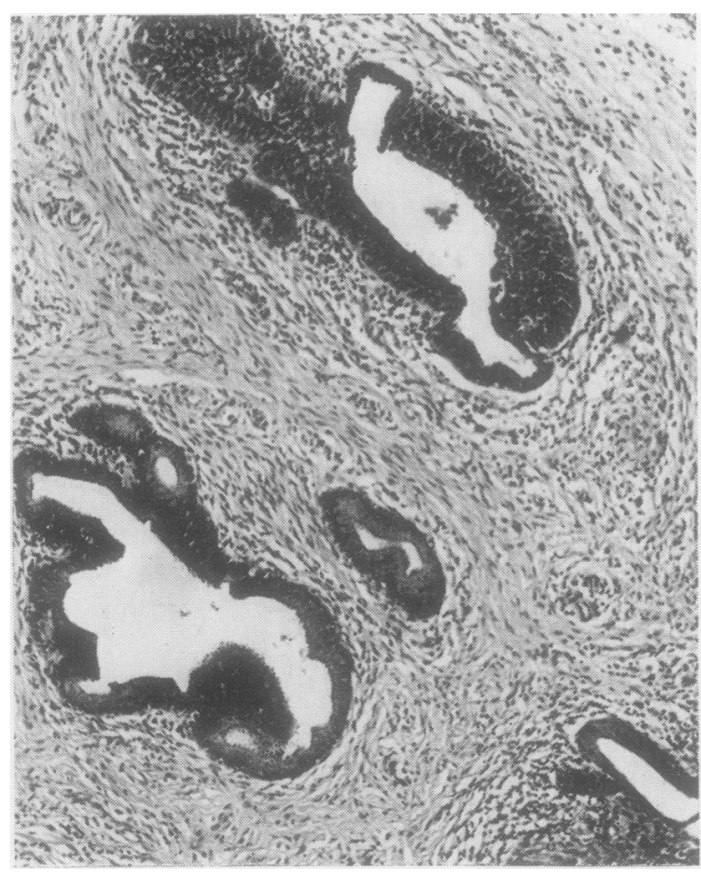

FIG. 5 .

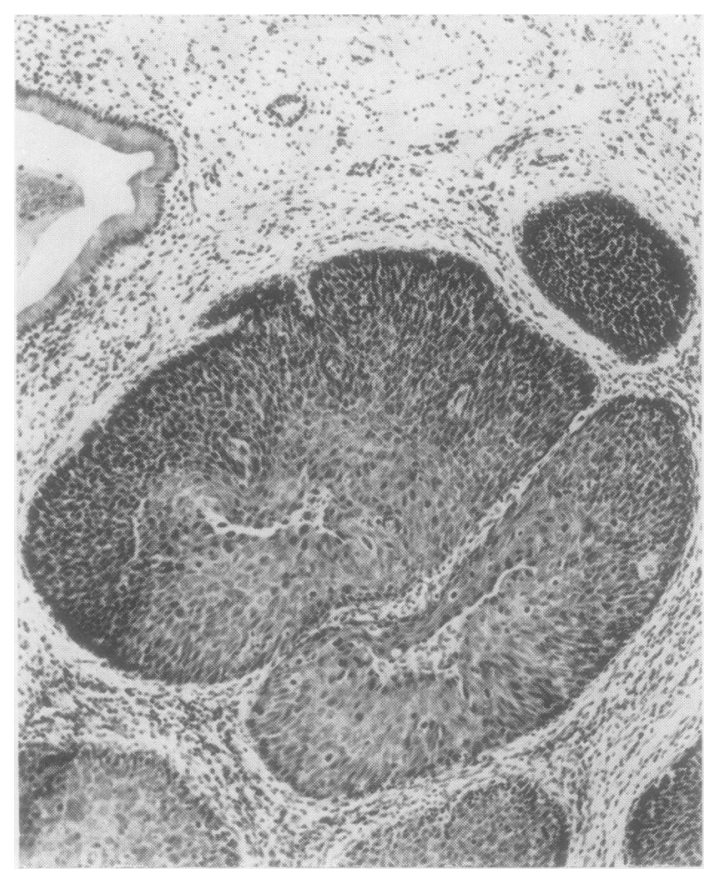

FIG. 6 .

FIGS. 5 and 6. Transitional celled preinvasive carcinoma of mucous glands; the field is immediately adjacent to that $\stackrel{\unrhd}{\unrhd}$ shown in Figure $4(\times 80)$ and extensive involvement of mucous glands by preinvasive squamous-celled carcinoma $(\times 76)$. Haematoxylin and eosin. 


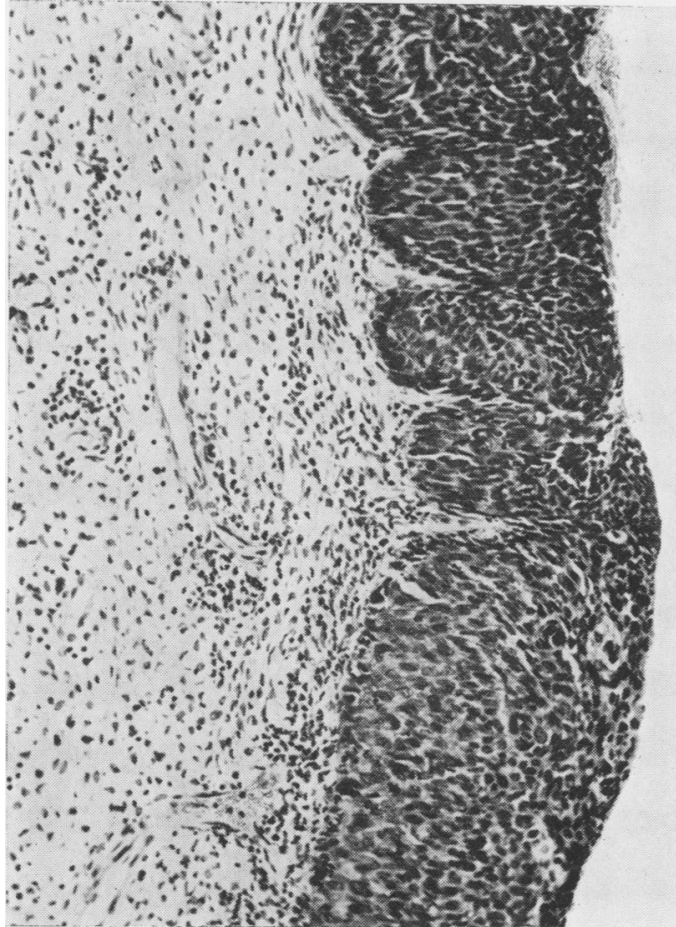

FIG. 7.

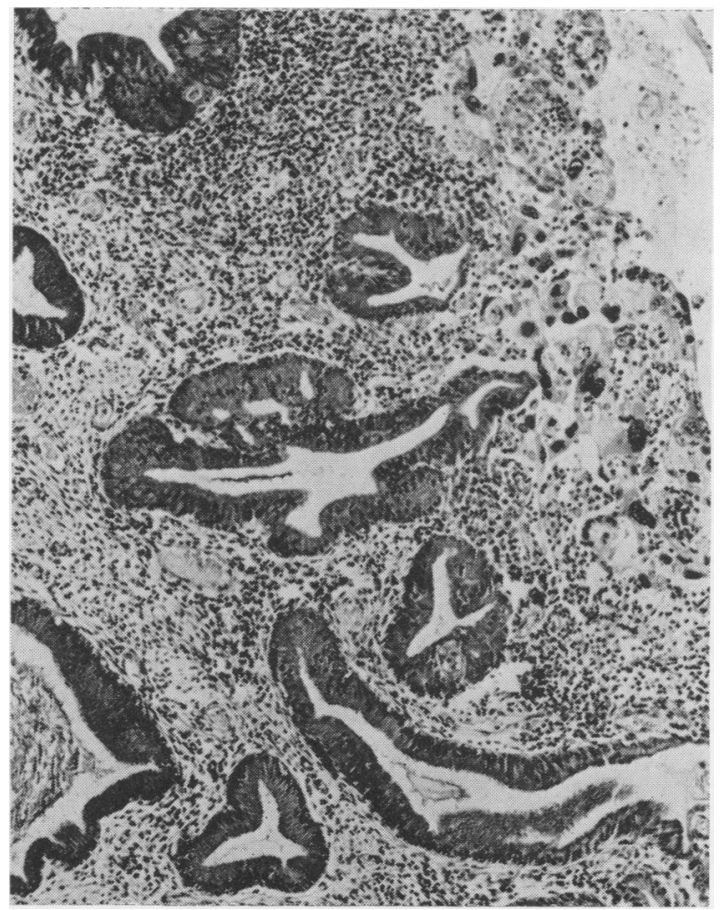

FIG. 9.



FIG. 8.

FIG. 7. Replacement of endocervical columnar epithelium by preinvasive transitional-celled carcinoma. Haematoxylin and eosin $\times 145$.

FIG. 8. Residual mucous glands completely unaffected by the proximity of endocervical epidermoid carcinoma. Haematoxylin and eosin $\times 105$.

FIG. 9. A very uncommon focal atypical glandular hyperplasia close to an endocervical squamous-celled carcinoma. Haematoxylin and eosin $\times 85$.

FIG. 10. Severe endocervical squamous metaplasia in a case of chronic cervicitis. Haematoxylin and eosin $\times 76$.

FIG. 11. A very uncommon direct transition from epithelial hyperplasia to an infiltrating exocervical squamouscelled carcinoma. Haematoxylin and eosin $\times 30$.

FIG. 12. Three normal parabasal epithelial cells close to a normal mature epithelial squame. Papanicolaou $\times 300$.

FIG. 13. A greatly hypertrophied parabasal epithelial cell close to a shrunken and distorted mature epithelial squame. The normal nuclear cytoplasmic ratio of the parabasal cell is preserved. Papanicolaou $\times 300$. 


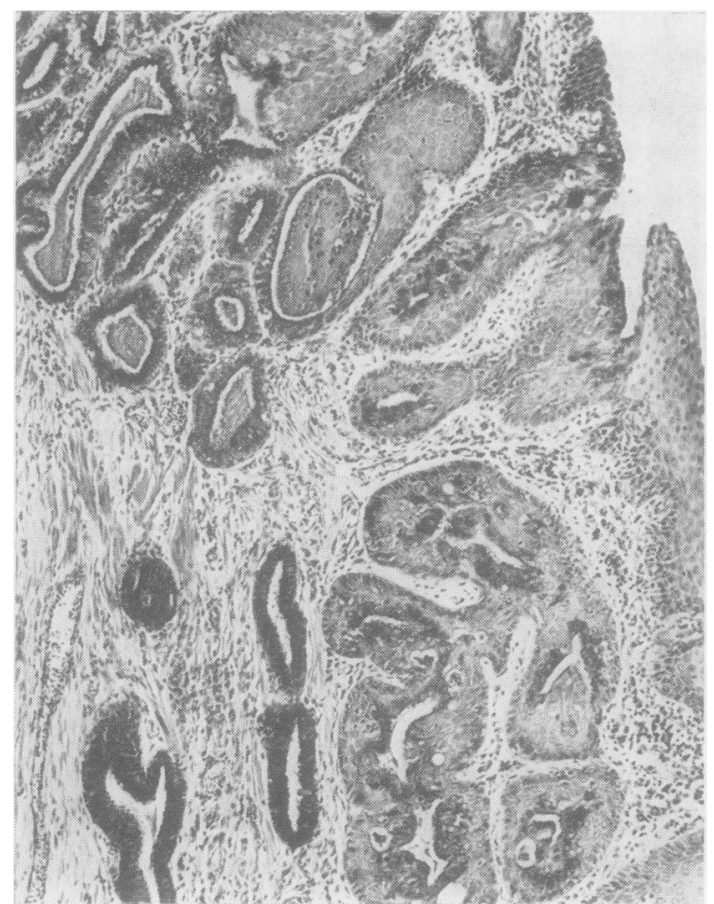

FIG. 10.

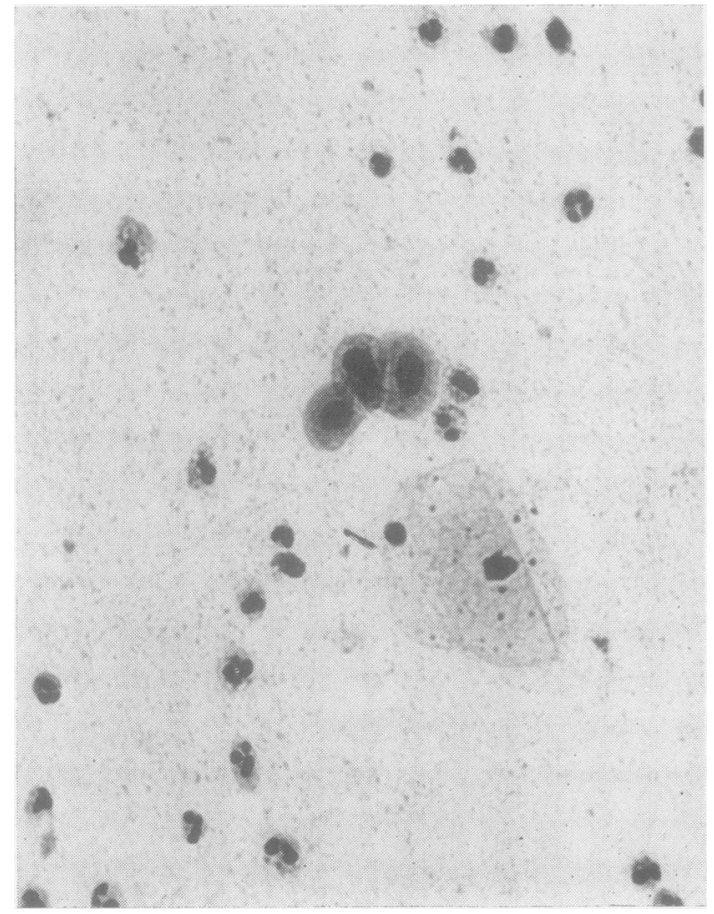

FIG. 12 .

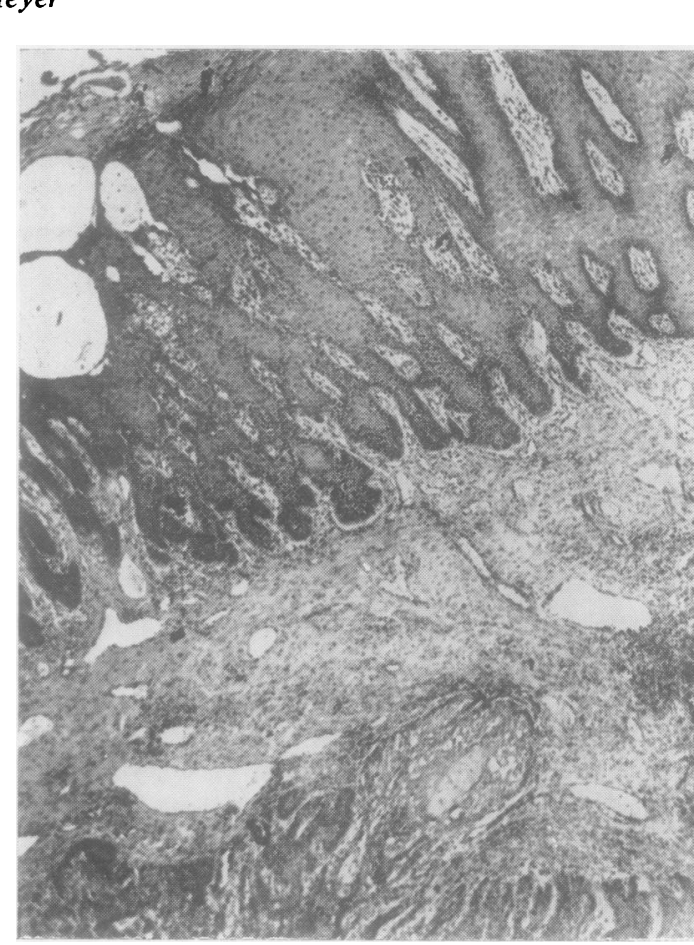

FIG. 11 .

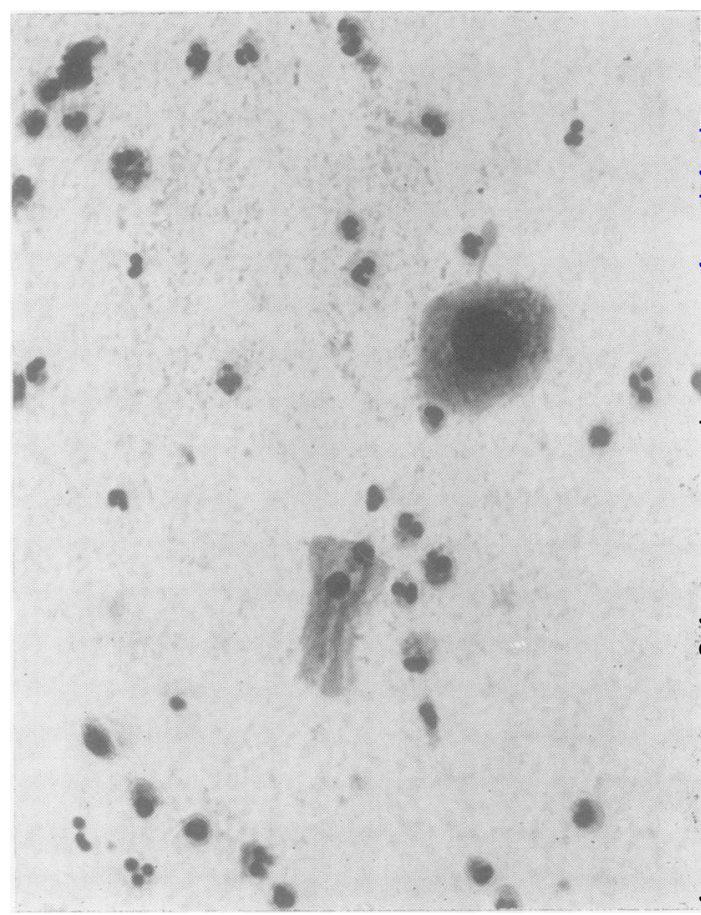

FIG. 13 . 


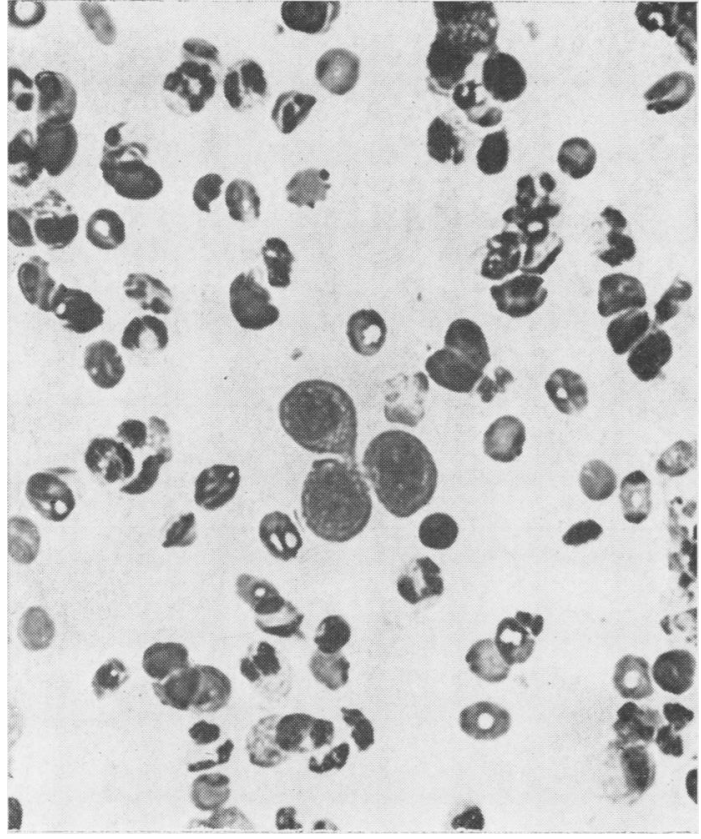

FIG. 14.

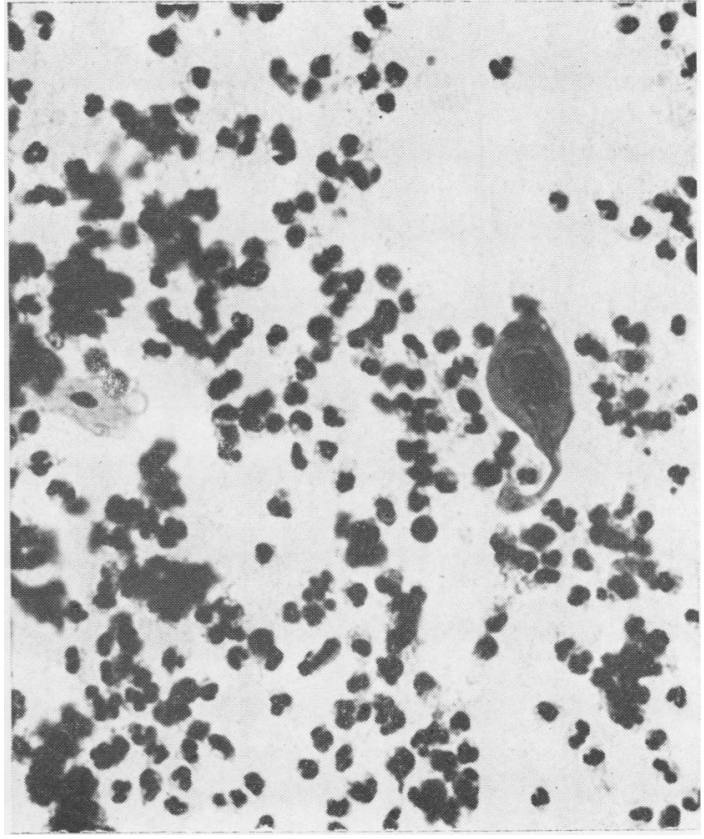

FIG. 15.

FIG. 14. A group of three small malignant cells of parabasal type with an intensely orange-coloured cytoplasm. The fading of the nuclei in the long interval since this film was prepared is a frequent occurrence. Papanicolaou $\times 400$. FIG. 15. A very uncommon type of malignant cell of 'tadpole' shape. Papanicolaou $\times 300$.

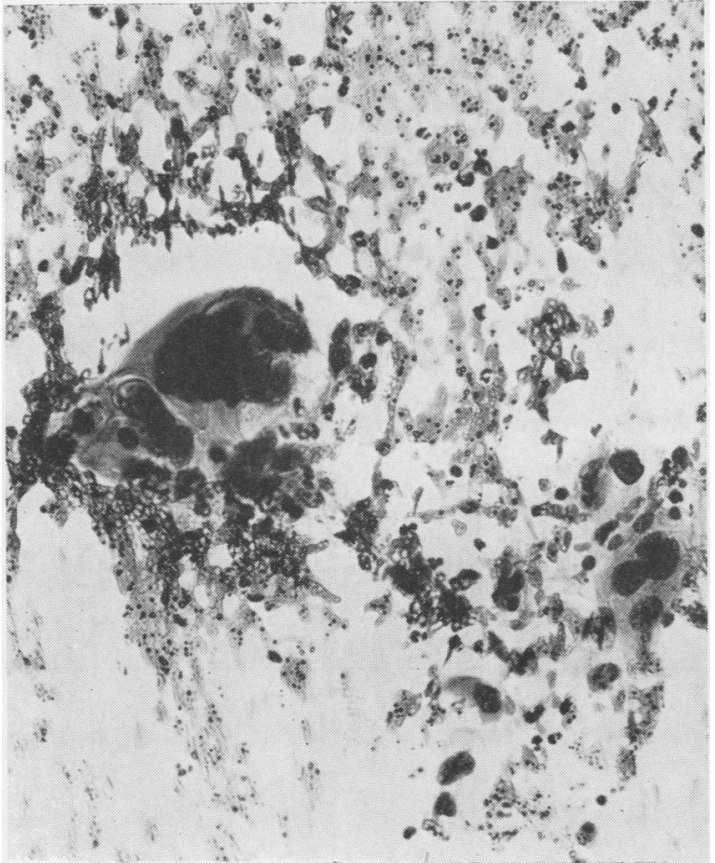

FIG. 16.

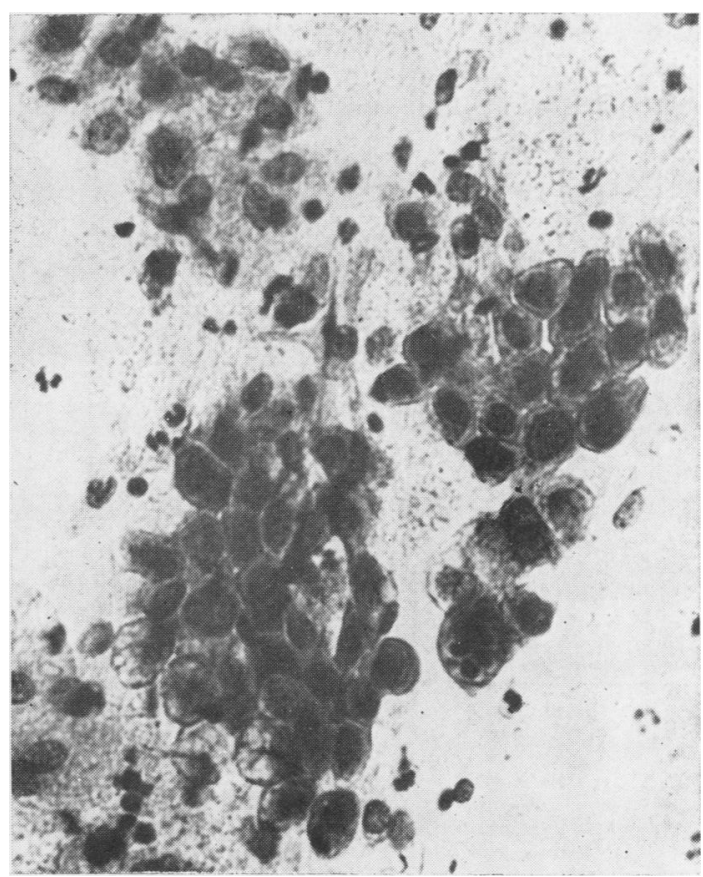

FIG. 17.

FIG. 16. Some very uncommon malignant cells of multinucleated giant-celled type. Papanicolaou $\times 300$.

FIG. 17. Some clusters of hypertrophic endocervical columnar epithelial cells showing a slight increase of the nuclear: cytoplasmic ratio but no pleomorphism; normal pregnancy. Papanicolaou $\times 300$. 
was obtained from the exocervix in 203 cases, from the endocervix in 85 cases, and from the junctional region in only 12 cases.

The relevant findings in the examples of preinvasive carcinoma, dysplasia, and hyperplasia are shown in Tables I and II. Squamous metaplasia was present in only two examples of infiltrating carcinoma; in each case the involvement was mimimal affecting $\overrightarrow{\bar{F}}$ only one and two mucous glands respectively.

A typical example of transitional-celled preinvasive

TABLE I

RESULTS IN CARCINOMA IN SITU

Case No. Site

Carcinoma in situ

Structure

\begin{tabular}{|c|c|c|c|c|c|}
\hline & & \multirow{3}{*}{ Structure } & & & \\
\hline & & & \multicolumn{2}{|l|}{ Extent } & \multirow{2}{*}{$\begin{array}{l}\text { Number of } \\
\text { Cell Layers } \\
\text { (Minimum and } \\
\text { Maximum) }\end{array}$} \\
\hline & & & $\begin{array}{l}\text { Surface Epithelium } \\
\text { (Low-power Fields) }\end{array}$ & Glandular Involvement & \\
\hline 1 & Exocervix & Squamous & 1 & - & 5- 9 \\
\hline 2 & Endocervix & Transitional & $\frac{1}{8}$ & - & $12-12$ \\
\hline 3 & Exocervix & Squamous & 3 & - & $8-16$ \\
\hline $4^{1}$ & Exocervix & Squamous & 6 & - & $11-28$ \\
\hline $6^{1}$ & Endocervix & Squamous & 10 & \multicolumn{2}{|c|}{ Many completely or partly replaced $11-14$} \\
\hline $7^{1}$ & $\begin{array}{l}\text { Exocervix and } \\
\text { endocervix }\end{array}$ & Squamous & 4 & \multicolumn{2}{|c|}{ Many completely or partly replaced $11-13$} \\
\hline 8 & Endocervix & Squamous & 1 & - & $16-20$ \\
\hline 9 & Endocervix & Transitional and squamous & 5 & Many completely replaced & $15-23$ \\
\hline $10^{1}$ & Endocervix & Squamous & 1 & Several completely replaced & $13-30$ \\
\hline 11 & Exocervix & Squamous & $\frac{1}{2}$ & - & $10-25$ \\
\hline $12^{1}$ & Endocervix & Squamous & - & \multicolumn{2}{|c|}{ Many completely or partly replaced - } \\
\hline 13 & $\begin{array}{l}\text { Exocervix and } \\
\text { endocervix }\end{array}$ & Squamous & $\frac{1}{2}$ & - & 24-30 \\
\hline 14 & $\begin{array}{l}\text { Exocervix and } \\
\text { endocervix }\end{array}$ & Transitional & 1 & A few completely replaced & $10-12$ \\
\hline 15 & Endocervix & Squamous & - & A few completely replaced & $10-20$ \\
\hline 16 & $\begin{array}{l}\text { Exocervix and } \\
\text { endocervix }\end{array}$ & Transitional and squamous & 1 & - & $20-30$ \\
\hline 17 & Exocervix & Transitional & $\frac{1}{2}$ & - & $12-15$ \\
\hline 18 & Endocervix & Transitional & - & One-half of one large gland & - \\
\hline 19 & $\begin{array}{l}\text { Exocervix and } \\
\text { endocervix }\end{array}$ & Transitional and squamous & 2 & $\begin{array}{l}\text { Several replaced: acinar } \\
\text { proliferation in some glands }\end{array}$ & $8-40$ \\
\hline 20 & Endocervix & Transitional & 2 & Many completely replaced & $7-12$ \\
\hline 21 & Exocervix & Transitional & $2 \frac{1}{2}$ & - & $10-26$ \\
\hline 22 & Endocervix & Squamous & - & Many completely replaced & - \\
\hline 23 & Endocervix & Transitional & $\frac{1}{2}$ & Several completely replaced & $9-12$ \\
\hline 24 & Endocervix & Transitional and squamous & 1 & Several completely replaced & $14-16$ \\
\hline 25 & Endocervix & Transitional and squamous foci & 4 & Many completely replaced & $12-28$ \\
\hline $26^{1}$ & Endocervix & Squamous & - & Two glands partly replaced & - \\
\hline $27^{1}$ & Endocervix & Transitional & $3 \frac{1}{2}$ & One gland completely replaced & $11-27$ \\
\hline $28^{1}$ & Endocervix & Squamous & $\frac{1}{2}$ & One gland completely replaced & $12-16$ \\
\hline
\end{tabular}

TABLE II

RESULTS IN DYSPLASIA AND HYPERPLASIA

Case No. Site

Dysplasia

Extent: Surface

Exithelium

(Low-power Fields)
Number of Cell

Layers (Minimum

and Maximum)
Hyperplasia

\begin{tabular}{|c|c|c|c|c|c|}
\hline & & & & \\
\hline & & $\begin{array}{l}\text { Extent: Surface } \\
\text { Epithelium } \\
\text { (Low-power Fields) }\end{array}$ & $\begin{array}{l}\text { Number of Cell } \\
\text { Layers (Minimum } \\
\text { and Maximum) }\end{array}$ & $\begin{array}{l}\text { Extent: Surface } \\
\text { Squamous Epithelium } \\
\text { (Low-power Fields) }\end{array}$ & $\begin{array}{l}\text { Number of Cell } \\
\text { Layers (Minimum } \\
\text { and Maximum) }\end{array}$ \\
\hline 6 & Endocervix and exocervix & 1 & $11-14$ & $1 \frac{1}{4}$ & $23-26$ \\
\hline 8 & Endocervix & 3 & $15-20$ & 一 & - \\
\hline 19 & Exocervix & - & - & 3 & $14-40$ \\
\hline 27 & Endocervix & $\frac{1}{2}$ & $14-20$ & - & - \\
\hline 28 & Exocervix & - & - & 8 & $11-18$ \\
\hline 29 & Exocervix & - & - & 4 & $25-30$ \\
\hline 30 & Exocervix & $\frac{1}{2}$ & $10-15$ & - & - \\
\hline 31 & Exocervix & - & - & 1 & $35-50$ \\
\hline 32 & Exocervix & - & - & $i$ & $40-50$ \\
\hline 33 & Exocervix & - & - & $3 \frac{1}{2}$ & $25-80$ \\
\hline 34 & Exocervix & - & 一 & 1 & $75-85$ \\
\hline 35 & Exocervix & - & - & 13 & $18-27$ \\
\hline 36 & Exocervix & - & - & $1 \frac{1}{2}$ & 25 \\
\hline
\end{tabular}


carcinoma affecting mucous glands is shown in Fig. 5 ; in this case the field is immediately adjacent to that illustrated in Figure 4. Extensive involvement of mucous glands by squamous-celled preinvasive carcinoma is shown in Fig. 6 while replacement of endocervical columnar epithelium by transitionalcelled preinvasive carcinoma is illustrated in Figure 7. It was found that the presence of an infiltrating carcinoma usually produced no effects on adjacent mucous glands (Fig. 8) but in one example (Fig. 9) there was a focal atypical glandular hyperplasia in the presence of an infiltrating squamous-celled carcinoma. For comparison, a typical example of squamous metaplasia from a case of simple chronic cervicitis is illustrated in Figure 10. A direct transition from a zone of hyperplasia to infiltrating carcinoma was an extremely uncommon finding and an example is illustrated in Figure 11.

It must be added that the numbers of the cases shown in Table III do not correspond to those shown in Table II since cervical smears were available from only four cases of preinvasive carcinoma; the remainder were obtained from examples of infiltrating carcinoma. For convenience the same four cases of preinvasive carcinoma shown in Table II have retained their original numbers and are marked by superscripts in Table III although this has caused discontinuity in the sequential numbering of the cases in the latter Table. Some of the cellular types mentioned in Table III are illustrated in Figs. 12-16, while for comparison some hypertrophic endocervical columnar cells from a normal pregnant woman are shown in Figure 17.

\section{DISCUSSION}

An increased nuclear to cytoplasmic ratio emerged as the most important diagnostic feature of cytological malignancy and this finding has been confirmed by several authors (Papanicolaou and Traut, 1943; Gates and Warren, 1950; Johnston, 1952; Reagan and Moore, 1952; Papanicolaou, 1954). The other findings listed in Table III were more inconstant although an intensely orange coloured cytoplasm in a small parabasal type of cell proved a valuable diagnostic feature; it is of interest that multinucleated giant cells of bizarre shape were only rarely observed. It is often claimed (Boddington, Cowdell, and Spriggs, 1960) that preinvasive carcinoma and invasive carcinoma cannot be distinguished cytologically and this was confirmed in the present study.

It is sometimes possible to render a definite diagnosis of cytological malignancy on the examination of a few atypical cells but it is the experience in most departments that cervical smears often show various degrees of cytological atypia; it is the usual practice to assign such smears to four or five appropriate grades, the interpretation of which for clinical purposes may be difficult. In view of the laborious nature of the work and the fact that the subjective diagnosis of cytological malignancy depends on simple physical criteria it has been the recent practice in the United States to carry out these investigations with the aid of physical instruments. These use simple mathematical measurements and such studies have been reported by Reagan, Hamonic, and Wentz (1957), Tolles, Horvath, and Bostrom (1961a, b) and Bostrom, Tolles, and Spencer (1962). The present histological study has shown that dysplasia, preinvasive carcinoma, and infiltrating carcinoma may coexist. In view of the random sampling of cells in cervical smears it appears unwise to formulate precise histological diagnoses on particular cytological distribution curves obtained by physical measurements, and the present tendency is to regard any positive smear as an indication for biopsy regardless of the degree of atypia observed (Hellwig, 1963).

It has sometimes been suggested (Novak and Galvin, 1951) that cytological diagnosis of preinvasive carcinoma is often not confirmed by study of the relevant histological material and that pathologists' definitions of preinvasive carcinoma must vary widely (Kirkland, 1963); it is a fact that false positive cytological diagnoses are sometimes made but also true that lesions are often minute and easily eradicated. Consideration of the findings in Table I shows that infiltrating carcinomas were surrounded by preinvasive zones up to $1.25 \mathrm{~cm}$. wide since the width of one low-power field was equal to $0.25 \mathrm{~cm}$. under the particular magnification used. Although less than one-tenth of the infiltrating tumours in this series showed this change it is clear that the evidence of a preinvasive phase must have been already obliterated in many cases. Nevertheless, the fact that mainly biopsy material from relatively early cases was studied suggests that by no means all infiltrating cervical carcinomas pass through a prolonged preinvasive phase.

While the laboratory services of this country could in general deal with the cytological material submitted from gynaecological clinics, it is clear that the mass screening of the adult female population at regular intervals would require an entirely different approach. It has been calculated that the submission of a cervical smear at three-yearly intervals from every parous woman between the ages of 25 and 60 would entail the examination of approximately 150 smears from a general practice including 2,000 patients (Brit. med. J., 1963) from which it is clear that the annual national turnover would amount to several million cytological examinations. It has 
TABLE III

SUMMARY OF CYTOLOGICAL FINDINGS

\begin{tabular}{|c|c|c|c|c|c|c|c|c|c|c|c|}
\hline \multirow[t]{2}{*}{$\begin{array}{l}\text { Case } \\
\text { No. }\end{array}$} & \multirow{2}{*}{$\begin{array}{l}\text { No. of Atypical Cells } \\
\quad<10=+ \\
10 \leq 50=++ \\
>50=+++\end{array}$} & \multicolumn{2}{|c|}{$\begin{array}{l}\text { Total Size Compared } \\
\text { with }\end{array}$} & \multirow[t]{2}{*}{$\begin{array}{l}\text { Shapes of } \\
\text { Cell }\end{array}$} & \multirow[t]{2}{*}{$\begin{array}{l}\text { Shapes of } \\
\text { Nucleus }\end{array}$} & \multirow[t]{2}{*}{$\begin{array}{l}\text { Area of } \\
\text { Nucleus }\end{array}$} & \multirow[t]{2}{*}{$\begin{array}{l}\text { Nuclear } \\
\text { Membrane }\end{array}$} & \multirow{2}{*}{$\begin{array}{l}\text { Nuclear } \\
\text { Chromatin } \\
\text { Pattern }\end{array}$} & \multirow{2}{*}{$\begin{array}{l}\text { Increased } \\
\text { Prominence } \\
\text { of Nucleoli }\end{array}$} & \multirow{2}{*}{$\begin{array}{l}\text { Cyto- } \\
\text { e plasmic } \\
\text { Colour }\end{array}$} & \multirow{2}{*}{$\begin{array}{l}\text { Nuclear } t \\
\text { Cyto- } \\
\text { plasmic } \\
\text { Ratio }\end{array}$} \\
\hline & & $\begin{array}{l}\text { Normal } \\
\text { Parabasal } \\
\text { Cells }\end{array}$ & $\begin{array}{l}\text { Normal } \\
\text { Mature } \\
\text { Squames }\end{array}$ & & & & & & & & \\
\hline 1 & $t+t$ & $\begin{array}{l}\text { Mostly } \\
\text { larger, som } \\
\text { anisocytosi }\end{array}$ & $\begin{array}{l}\text { Smaller } \\
\text { me } \\
\text { sis }\end{array}$ & $\begin{array}{l}\text { Elongated, } \\
\text { oval, } \\
\text { irregular, } \\
\text { tadpole }\end{array}$ & $\begin{array}{l}\text {, Circular, } \\
\text { irregular }\end{array}$ & Increased & Indistinct & Pyknotic & + & Orange & Increased \\
\hline 2 & $+t$ & L.arger & Smaller & $\begin{array}{l}\text { Oval, } \\
\text { irregular }\end{array}$ & $\begin{array}{l}\text { Circular, } \\
\text { oval }\end{array}$ & Increased & Indistinct & Pyknotic & - & $\begin{array}{l}\text { Orange, } \\
\text { green }\end{array}$ & Increased \\
\hline 3 & $+t$ & $\begin{array}{l}\bumpeq \text { some } \\
\text { aniso- } \\
\text { cytosis }\end{array}$ & $\begin{array}{l}\text { Much } \\
\text { smaller }\end{array}$ & Oval & Circular & $\begin{array}{l}\text { Slightly } \\
\text { increased }\end{array}$ & Normal & $\begin{array}{l}\text { Accen- } \\
\text { tuated }\end{array}$ & - & $\begin{array}{l}\text { Intense } \\
\text { orange }\end{array}$ & Increas \\
\hline $4^{1}$ & $t+t$ & Larger & Smaller & Oval & $\begin{array}{l}\text { Circular, } \\
\text { oval }\end{array}$ & Increased & Normal & Pyknotic & - & Orange & Increased \\
\hline 5 & + & $\begin{array}{l}\text { Slightly } \\
\text { larger }\end{array}$ & $\begin{array}{l}\text { Much } \\
\text { smaller }\end{array}$ & $\begin{array}{l}\text { Elongated, } \\
\text { oval }\end{array}$ & $\begin{array}{l}\text {, Circular, } \\
\text { oval }\end{array}$ & $\begin{array}{l}\text { Slightly } \\
\text { increased }\end{array}$ & Normal & $\begin{array}{l}\text { Accen- } \\
\text { tuated }\end{array}$ & - & $\begin{array}{l}\text { Intense } \\
\text { orange }\end{array}$ & $\begin{array}{l}\text { Some } \\
\text { normal, } \\
\text { some } \\
\text { increased }\end{array}$ \\
\hline 6 & + & Smaller & $\begin{array}{l}\text { Much } \\
\text { smaller }\end{array}$ & Oval & Circular & No change & e Normal & $\begin{array}{l}\text { Accen- } \\
\text { tuated }\end{array}$ & - & $\begin{array}{l}\text { Intense } \\
\text { orange }\end{array}$ & Increased \\
\hline 7 & $t+t$ & $\begin{array}{l}\text { Larger, } \\
\text { some } \\
\text { aniso- } \\
\text { cytosis }\end{array}$ & Smaller & Oval & $\begin{array}{l}\text { Circular, } \\
\text { oval, } \\
\text { irregular }\end{array}$ & Increased & Normal & Pyknotic & + & $\begin{array}{l}\text { Green, } \\
\text { ampho- } \\
\text { philic }\end{array}$ & Increasec \\
\hline 8 & $4+$ & $\begin{array}{l}\text { Much } \\
\text { aniso- } \\
\text { cytosis }\end{array}$ & Smaller & $\begin{array}{l}\text { Elongated, } \\
\text { oval, } \\
\text { irregular, } \\
\text { tadpole }\end{array}$ & $\begin{array}{l}\text { Circular, } \\
\text { oval, } \\
\text { irregular }\end{array}$ & Increased & Normal & Pyknotic & - & $\begin{array}{l}\text { Intense } \\
\text { orange }\end{array}$ & Increased \\
\hline 9 & ++ & Larger & $\begin{array}{l}\text { Smaller, } \\
\text { except } \\
\text { giant cells }\end{array}$ & $\begin{array}{l}\text { Oval, } \\
\text { irregular }\end{array}$ & $\begin{array}{l}\text { Circular, } \\
\text { oval }\end{array}$ & Increased & Normal & Pyknotic & - & $\begin{array}{l}\text { Green, } \\
\text { ampho- } \\
\text { philic }\end{array}$ & Increased \\
\hline 10 & $++\dot{+}$ & $\begin{array}{l}\text { Larger, } \\
\text { some } \\
\text { aniso- } \\
\text { cytosis }\end{array}$ & Smaller & Oval & $\begin{array}{l}\text { Circular, } \\
\text { oval }\end{array}$ & Increased & Normal & Pyknotic & - & $\begin{array}{l}\text { Green, } \\
\text { ampho- } \\
\text { philic, a } \\
\text { few orange }\end{array}$ & $\begin{array}{l}\text { Increased } \\
\text { e }\end{array}$ \\
\hline 11 & $+t+$ & $\begin{array}{l}\text { Larger, } \\
\text { some } \\
\text { aniso- } \\
\text { cytosis }\end{array}$ & Smaller & $\begin{array}{l}\text { Oval, } \\
\text { irregular }\end{array}$ & $\begin{array}{l}\text { Circular, } \\
\text { oval, } \\
\text { irregular }\end{array}$ & Increased & Normal & Pyknotic & - & $\begin{array}{l}\text { Green, } \\
\text { ampho- } \\
\text { philic, } \\
\text { orange }\end{array}$ & Increased \\
\hline 12 & $t$ & Larger & Smaller & Oval & $\begin{array}{l}\text { Circular, } \\
\text { oval }\end{array}$ & Increased & Normal & Pyknotic & - & $\begin{array}{l}\text { Orange, } \\
\text { green }\end{array}$ & Increased \\
\hline 13 & $t+t$ & $\begin{array}{l}\text { Larger, } \\
\text { some } \\
\text { aniso- } \\
\text { cytosis }\end{array}$ & Smaller & Oval & $\begin{array}{l}\text { Circular, } \\
\text { oval, } \\
\text { irregular }\end{array}$ & Increased & Normal & Pyknotic & - & Orange & Increas \\
\hline 14 & $++t$ & Larger & Smaller & $\begin{array}{l}\text { Elongated, } \\
\text { oval, } \\
\text { irregular }\end{array}$ & $\begin{array}{l}\text { Circular, } \\
\text { oval, } \\
\text { irregular }\end{array}$ & Increased & Normal & Pyknotic & - & $\begin{array}{l}\text { Orange, } \\
\text { green }\end{array}$ & Increased \\
\hline $26^{1}$ & $+t$ & $\begin{array}{l}\bumpeq \text { some } \\
\text { aniso- } \\
\text { cytosis }\end{array}$ & Smaller & Irregular & $\begin{array}{l}\text { Circular, } \\
\text { irregular }\end{array}$ & $\begin{array}{l}\text { Slightly } \\
\text { increased }\end{array}$ & Indistinct & Pyknotic & - & Orange & Increased \\
\hline $27^{1}$ & +++ & $\begin{array}{l}\simeq \text { some } \\
\text { aniso- } \\
\text { cytosis }\end{array}$ & Smaller & $\begin{array}{l}\text { Elongated, } \\
\text { oval, } \\
\text { irregular }\end{array}$ & $\begin{array}{l}\text { Circular, } \\
\text { oval }\end{array}$ & Increased & $\begin{array}{l}\text { Accen- } \\
\text { tuated }\end{array}$ & $\begin{array}{l}\text { Accen- } \\
\text { tuated }\end{array}$ & - & $\begin{array}{l}\text { Intense } \\
\text { orange, } \\
\text { ampho- } \\
\text { philic }\end{array}$ & Increased \\
\hline $28^{1}$ & + & $\bumpeq$ & $\begin{array}{l}\text { Much } \\
\text { smaller }\end{array}$ & $\begin{array}{l}\text { Elongated, } \\
\text { oval }\end{array}$ & , Oval & No change & Indistinct & Pyknotic & - & $\begin{array}{l}\text { Intense } \\
\text { orange }\end{array}$ & Normal \\
\hline
\end{tabular}

also been estimated that the cost of detection of one case of early cervical carcinoma is about $£ 60$, approximately the same as for a case of pulmonary tuberculosis detected by mass radiography (Macgregor and Baird, 1963).

Although mass cytological screening projects have many advocates (Way, Duran, Peberdy, and Stefan, 1963) and there is increasing pressure on laboratories to undertake this work, some authors remain sceptical (Corbett, 1962; McKinnon, 1963) while a few, such as Howell (1961), have been daunt $\frac{\Phi}{8}$ ed by the magnitude of the task. Foote and $\mathrm{Li} \mathrm{(1948)})^{-}$ stated that a total of 500 hours must be spent at microscopy to detect one case of cervical carcinom in a screening programme; although the true figure is probably much lower (Wilson, 1961), it is cleå that the major obstacle to the implementation of large screening programmes is the acute shortage of 
trained cytologists (Day, 1956)). The restriction of a laboratory technician to this narrow field of work as suggested by Way (1963) is not a sound proposition since no individual could be expected to examine more than $\mathbf{4 0}$ slides per day and a figure of $\mathbf{2 0}$ per day is more realistic (Faulds, 1964).

In these circumstances it is far more realistic to carry out the screening of cervical smears by means of automatic cytoanalysing machines of which prototypes exist in the United States of America. The resultant saving of cost and manpower would mean that far greater resources could be devoted to detailed studies of untreated cases of premalignant cervical conditions as suggested by Bamforth and Cardell (1962) and to the establishment of cytology registries such as the one described at the Lahey Clinic by Copenhaver and Bahner (1963).

I am indebted to Mr. G. W. Moore for the preparation of the photomicrographs.

\section{REFERENCES}

Bamforth, J., and Cardell, B. S. (1962). J. Obstet. Gynaec. Brit. Cwlth, 69, 379.

Beale, L. S. (1867). The Microscope in its Application to Practical Medicine, 3rd ed., p. 258. Churchill, London.

Boddington, M. M., Cowdell, R. H., and Spriggs, A. I. (1960). Brit. J. Cancer, 14, 151.

Bostrom, R. C., Tolles, W. E., and Spencer, C. C. (1962). Acta cytol. (Philad.), 6, 417.

British Medical Journal 1963. Leading article. 1, 1625.

Broders, A. C. (1932). J. Amer. med. Ass., 99, 1670.

Carson, R. P., and Gall, E. A. (1954). Amer. J. Path., 30, 15

Copenhaver, E. H., and Bahner, D. R. (1963). Amer. J. Obstet. Gynec., 86, 937.

Corbett, H. V. (1962). Brit. J. clin. Pract., 16, 571.

Dart, L. H. Jr., and Turner, T. R. (1959). Lab. Invest., 8, 1513.

Day, E. (1956). Ann. N.Y. Acad. Sci., 63, 1070.

De Brux, J., and Wenner-Mangen, H. (1961). Acta cytol. (Philad.), $5,349$.

Elevitch, F. R., and Brunson, J. G. (1961). Surg. Gynec. Obstet., $112,3$.

Faulds, J. S. (1964). Lancet, 1, 655.

Figge, D. C., de Alvarez, R. R., Brown, D. V., and Fullington, W. R. (1962). Amer. J. Obstet. Gynec., 84, 638.
Foote, F. W., and Li, K. (1948). Ibid., 56, 335.

Galvin, G. A., Jones, H. W., and Te Linde, R. W. (1955). Ibid., 70, 808 .

Gates, O., and Warren, S. (1950). A Handbook for the Diagnosis of Cancer of the Uterus by the Use of Vaginal Smears, 3rd ed. p. 43. Harvard University Press, Cambridge, Mass.

Hellwig, C. A. (1963). J. int. Coll. Surg., 40, 465.

Holland, J. C., and Ackermann, M. R. (1961). Obstet. and Gynec., $17,38$.

Howell, D. (1961). Med. J. Aust., 2, 163.

Johnston, D. G. (1952). Cancer (Philad.), 5, 945.

Kaplan, L., Masin, F., Masin, M., Carleton, R., and von Bertalanffy, L. (1960). Amer. J. Obstet. Gynec., 80, 1063.

Kirkland, J. A. (1963). J. clin. Path., 16, 150.

Koss, L. G., and Durfee, G. R. (1956). Ann. N.Y. Acad. Sci., 63, 1245. Stewart, F. W., Foote, F. W., Jordan, M. J., Bader, G. M., and Day, E. (1963). Cancer (Philad.), 16, 1160.

Macgregor, J. E., and Baird, D. (1963). Brit. med. J., 1, 1631.

McKinnon, N. E. (1963). Canad. med. Ass. J., 88, 295.

Nieburgs, H. E. (1963). Cancer (Philad.), 16, 141.

Novak, E. R., and Galvin, G. A. (1951). Amer. J. Obstet. Gynec., 62, 1079.

Okagaki, T., Lerch, V., Younge, P. A., McKay, D. G., and Kevorkian, A. Y. (1962). Acta cytol. (Philad.), 6, 343.

Papanicolaou, G. N. (1942). Science, 95, 438.

(1954). Atlas of Exfoliative Cytology, p. 14. Harvard University Press, Commonwealth Fund, Cambridge, Mass.

- and Traut, H. F. (1943). Diagnosis of Uterine Cancer by the Vaginal Smear. The Commonwealth Fund, New York.

Petersen, O. (1955). Acta radiol. (Stockh.), suppl., 127, 79.

Reagan, J. W., Hamonic, M. J., and Wentz, W. B. (1957). Lab. Invest., 6, 241.

—, Hicks, D. J., and Scott, R. B. (1955). Cancer (Philad.), 8, 42. and Moore, R. D. (1952). Amer. J. Path., 28, 105.

_- Seidemann, I. L., and Saracusa, Y. (1953). Cancer (Philad.), 6, 224.

Richart, R. M. (1963). Amer. J. Obstet. Gynec., 86, 925.

Schauenstein, W. (1908). Arch. Gynäk., 85, 576.

Schottlaender, J., and Kermauner, F. (1912). Zur Kenntnis des Uteruskarzinoms, p. 585. Karger, Berlin.

Stern, E. (1959). Cancer (Philad.), 12, 933.

Tolles, W. E., Horvath, W. J., and Bostrom, R. C. (1961a). Cancer (Philad.), 14, 437.

Törnberg, B., Westin, B., and Norlander, A. (1960). Acta obstet. gynec. scand., 39, 517.

von Bertalanffy, L., Masin, F., and Masin, M. (1956). Science, $124,1024$.

Way, S. (1963). The Diagnosis of Early Carcinoma of the Cervix: a Practical Handbook, p. 26. Churchill, London.

Duran, F., Peberdy, M., and Stefan, M. A. (1963). Lancet, 2,624 .

Williams, J. (1888). Cancer of the Uterus, p. 73. Lewis, London.

Wilson, J. M. G. (1961). Mth. Bull. Minist. Hlth. Lab. Serv., 20, 214. 